\title{
Geospatial analysis of drought tendencies in the Carpathians as reflected in a 50 -year time series
}

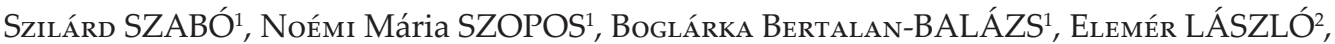 \\ Dragan D. MILOŠEVIĆ ${ }^{3}$, Christian CONOSCENTI ${ }^{4}$ and IsTVÁN LÁZÁR ${ }^{5}$
}

\begin{abstract}
Climate change is one of the most important issues related to anthropogenic activities. The increasing drought conditions can cause water shortage and heat waves and can influence the agricultural production or the water supply of cities. The Carpathian region is also affected by this phenomenon; thus, we aimed at identifying the tendencies between 1960 and 2010 applying the CarpatClim (CC) database. We calculated the trends for each grid point of CC, plotted the results on maps, and applied statistical analysis on annual and seasonal level. We revealed that monthly average temperature, maximum temperature and evapotranspiration had similar patterns and had positive trends in all seasons except autumn. Precipitation also had a positive trend, but it had negative values in winter. The geospatial analysis disclosed an increasing trend from West to East and from north to west. A simple binary approach (value of 1 above the upper quartile in case of temperature and evapotranspiration, value of 1 below the lower quartile; 0 for the rest of the data) helped to identify the most sensitive areas where all the involved climatic variables exceeded the threshold: Western Hungary and Eastern Croatia. Results can help to prepare possible mitigation strategies for climate change to help both landowners and planners to draw the conclusions.
\end{abstract}

Keywords: CarpatClim, climatic change, trend, robust comparisons, sensitivity

\section{Introduction}

Drought is a crucial point among the challenges of climate change. There are hot spot areas where drought is a living problem. It is the consequence of the climate and can be regarded as a natural phenomenon, due to temperature increase and precipitation decrease. Large areas are endangered on global scale (MoLnÁR, K. and MikA, J. 1997; KertésZ, Á. and MiKa, J. 1999; Bradford, R.B. 2000; Wilhite, D.A. 2000).
When drought is not just a recurring temporal deviation of a region's climate but it occurs permanently, the phenomenon is called aridification: the length and intensity of the drought periods increase exceeding seasonal changes; furthermore, the increase has a positive trend (TAte, E.L. and Gustard, A. 2000). The trends of annual mean temperature changes are identified (MeenL, G.A. et al. 2007). The consciousness of the countries has improved, 168 countries signed the Paris Agreement.

\footnotetext{
${ }^{1}$ Department of Physical Geography and Geoinformatics, Faculty of Technology and Sciences, Doctoral School of Earth Sciences, University of Debrecen, H-4032 Debrecen, Egyetem tér 1. E-mails: szabo.szilard@science. unideb.hu, szopos.noemi@science.unideb.hu, balazs.boglarka@science.unideb.hu

${ }^{2}$ Isotope Climatology and Environmental Research Centre, Institute for Nuclear Research, Hungarian Academy of Sciences, H-4026 Debrecen, Bem tér 18/C. E-mail: laszlo.elemer@atomki.mta.hu

${ }^{3}$ Climatology and Hydrology Research Centre, Faculty of Sciences, University of Novi Sad, Trg Dositeja Obradovića 3, Novi Sad 21000, Serbia. E-mail: dragan.milosevic@dgt.uns.ac.rs

${ }^{4}$ Department of Earth and Marine Sciences (DISTEM), University of Palermo, Via Archirafi 22, 90123 Palermo, Italy. E-mail: christian.conoscenti@unipa.it

${ }^{5}$ Department of Meteorology, Faculty of Technology and Sciences, University of Debrecen, H-4032 Debrecen, Egyetem tér 1. E-mail: lazar.istvan@science.unideb.hu
} 
The Carpathian region is also influenced by several negative consequences, especially the Great Hungarian Plain which is the largest flat area of the region. The lowlands of the region are rather warm and their water supply depends on the availability of runoff water from the surrounding mountains. Mountains and hilly areas are cooler and usually get more precipitation. However, both plains and mountains are influenced by climate change. The intensifying drought generates several problems: mineral dust particle transmission (VArGa, G. and Roettig, C.-B. 2018), shrinkage of water resources (Szalai, S. et al. 2000; Kertész, Á. 2016; Kundrát, J.T. et al. 2016), lower yields (DЕÁK, B. et al. 2014; VALKó, O. et al. 2014; MiLOŠEviĆ, D. et al. 2015; RAY, D.K. et al. 2015). It threatens even the optimal composition of habitats (ТӧRöк, P. et al. 2018), accelerates the spread of invasive species (Hellmann, J.J. et al. 2008), facilitates wildfires (DеÁк, B. et al. 2014).

Several studies dealt with the predicted changes for the Carpathian region pointing to the fact that the region will face substantial changes. BARTHoly, J. et al. (2009), Mika, J. (2009), Mezósi, G. et al. (2016), and BARTHoly, J. et al. (2015) reported on the increasing probability of heavy rains and as a consequence of this the increasing value of the erosivity factor (it can reach the double of the present value) using climate models (ALADIN, REMO, RCM, PRECIS) and predictions to 2100. If this scenario comes true, the agricultural production has to be prepared for the larger precipitation amounts coming from single events. Pongrácz, R. et al. (2014) projected relevant changes for the summers in the $21^{\text {st }}$ century for Central Europe; furthermore, Blanka, V. et al. (2013) found that a $4-8{ }^{\circ} \mathrm{C}$ increase can be expected up to 2100 , and the most endangered area is the Great Hungarian Plain. Garamhegyi, T. et al. (2018) and PÁlfai, I. and Herceg, Á. (2011) indicated the hazard of drought in the Carpathian Basin and in the Balkan area. Kovács, F. (2018) and GulácsI, A. and KovÁcs, F. (2018) applied satellite images with spectral indices and on the basis of a 18 years data series they found that a relevant decline of biomass can be expected due to the dry periods.

Previous studies proved the negative effects of climate change tendencies using mainly the climatic variables in the analyses. Based on a limited number of stations included the CarpatClim dataset it is possible to analyse both the features of the data series of the climatic variables and spatial characteristics at the same time. Our objective was therefore to perform a thorough research on the trends. Our hypothesis is as follows: (1) there is a positive trend regarding temperature and a negative trend concerning precipitation, (2) there is an increasing trend from West to East and from North to South regarding climatic variables.

\section{Methods}

\section{Study area}

The CarpatClim dataset covers 470,700 km², including 9 countries (Croatia, Czech Republic, Hungary, Poland, Romania, Serbia, Slovakia, Bulgaria and Ukraine) mainly in the region of the Carpathians, including mountains and basins. Corresponding to the large East-West $(750 \mathrm{~km})$ and North-South $(650 \mathrm{~km})$ distances and to the big range of elevation differences $(\sim 50-2,655 \mathrm{~m})$, the climatic conditions also have a large variance.

The average annual temperature in the Carpathian Basin in the cold season has a decrease from W-SW to E-NE. The higher values are about $-1{ }^{\circ} \mathrm{C}$ in the western part of Hungary and in the northern part of Serbia gradually decreasing towards the Eastern and Southern Carpathians by $-3,-4{ }^{\circ} \mathrm{C}$. In the Carpathians the lowest temperatures are below $-9{ }^{\circ} \mathrm{C}$. In July, however, the average temperature increases from northwest to southeast from $18{ }^{\circ} \mathrm{C}$ to $23^{\circ} \mathrm{C}$, but in the higher mountains, locally in the closed basins and on the highest peaks, the temperature does not exceed $10{ }^{\circ} \mathrm{C}$. In the western part of the area the cool oceanic air masses coming from the west have a relevant influence on the cli- 
mate, and this effect diminishes until the line of the Danube and increasing continentality plays the prevailing role. (Rusu, T. et al. 2014).

We divided the study area into a chessboard-like smaller set of regions (Figure 1). In the text, we referred to the regions with "\#” sign.

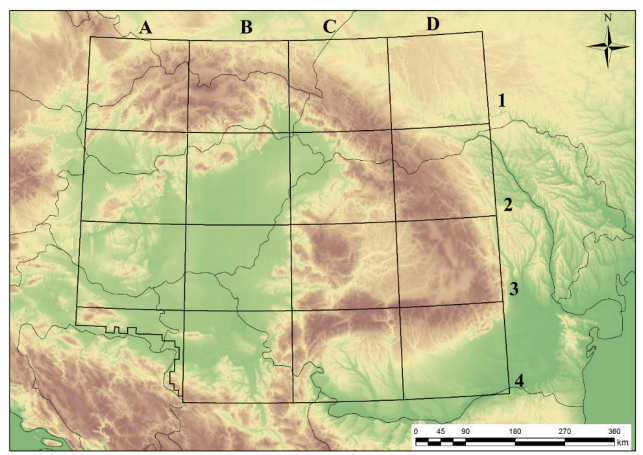

Fig. 1. Location of the study area, including the country borders and the grid for spatial analysis

The distribution of precipitation in the Carpathians is uneven in time with most precipitation occurring in late spring and early summer. The amount varies between 500-1,700 mm annually. In July in some areas, mainly on the lowlands the lowest value is $50-100 \mathrm{~mm}$ and the biggest value is almost $250 \mathrm{~mm}$ (Carpathian Mountains and Apuseni Mountains, \#C3). The drought period in the Great Hungarian Plain (\#B2 and \#B3) is from July to August due to the effects of the high pressure atmospheric systems (DövéNYI, Z. 2010; BiHARI, Z. et al. 2018). The above characterization is based on the CarpatClim Atlas.

\section{Datasets}

\section{Climatic data}

Climatic variables were obtained from the CarpatClim (CC) database (LaKatos, M. et al. 2013; Spinoni, J. et al. 2015a,b). CC is published as a free source of several climatic factors as an initiation to provide data for better international co-operations regarding environmental issues. The spatial resolution is $0.1^{\circ} \times 0.1^{\circ}$ and covers 9 countries in $\sim 470,700 \mathrm{~km}^{2}$ with 5,895 grid points in a time range of 1960-2010. The dataset is homogenized with the (Multiple Analysis of Series for Homogenization) MASH method, which is important because of missing data and possible differences of measuring protocols (Lakatos, M. et al. 2011; Szentimrey, T. 2011). There were more than 300 stations for temperature and more than 600 stations for precipitation data as input for the interpolation with the Meteorological Interpolation based on the Surface Homogenized Data Basis (MISH) method (SzEnTIMreY, T. and BiHARI, Z. 2007; Szentimrey, T. et al. 2010; SzentimREY, T. et al. 2012). Data are available on daily, monthly and yearly basis, we used monthly data in the analyses. We involved the monthly maximum temperature (TMAX), average temperature (TA), potential evapotranspiration (PET) and precipitation (PREC).

\section{Topographic data}

We applied the Shuttle Radar Topography Mission (SRTM) data with the void filled SRTM-Plus SRTM NASA V3 version (NASA Jet Propulsion Laboratory, 2013). The original data were retrieved in 2000 with a C-band and X-band radar interferometry sensor of the Space Shuttle Endeavour, SRTM Plus was released in 2013. It has $30 \mathrm{~m}$ geometric resolution and according to Szabó, G. et al. (2015) the mean vertical error is less than 5 $\mathrm{m}$ in Hungary.

\section{Data pre-processing}

We performed trend line fitting using regression analyses in each point of the time series of the CC-grid. As in 2009 and 2010 the amount of precipitation was unusually higher than during the previous years (MórING, 
A. 2011; SpINONI, J. et al. 2015a,b), we excluded them from the analysis to decrease the bias rising from this temporal occurrence. The equation of the regression analysis consists of the intercept $\left(\beta_{0}\right)$ where the fitted line intercepts the vertical axis, and the gradient of the fitted line $\left(\beta_{1}\right)$ which is the multiplier of the independent variable. The general form of an equation is Eq. 1, where the model error $\left(\varepsilon_{i}\right)$ is also presented (FIELD, A. et al. 2012).

$$
Y_{i}=\left(\beta_{0}+\beta_{1} x_{i}\right)+\varepsilon_{i}
$$

Accordingly, $\beta_{1}$ reflects the change in the dependent variable $(Y)$ against a unit change of the independent variable. In our case, we worked with the dataset as a time series, we analysed the changes along the time range between 1960 and 2010 (as independent variable), while the dependent variable was the given climatic variable (TMAX, TA, PET or PREC). We performed the trend line fitting on the annual data; furthermore, we repeated it with separating the months into seasonal groups: spring (March-May), summer (JuneAugust), autumn (September-November) and winter (December-February). Thus, we were able to analyse both the annual (i.e. general) and seasonal (i.e. specific) changes.

The statistical modelling and the extraction of $\beta_{1}$ values were performed in $\mathrm{R} 3.5 .2$ environment (R Core Team, 2018) using the $\mathrm{R}$ language for scripting. The $\beta_{1}$ values served as input data for statistical analysis.

\section{Statistical analysis}

We summarized the resulting $\beta_{1}$ values with median and ranges with violin plots combined with boxplots. Violin plots show the kernel probability density at different values. For seasonal changes, differences were analysed with robust ANOVA with robust post hoc test using trimmed means (20\%) combined with bootstrapping (599 replications) with the t1waybt() function, the same robust approach was applied for the post hoc pairwise comparisons with the mcpp20() func- tion (FIELD, A. et al. 2012). The trimmed mean approach handles the outliers of the dataset, while bootstrapping, which is a resampling technique with replacement, i.e. random sampling from the whole dataset (usually 99-9999 times) helps to calculate the accuracy of the existing data by quantifying the variance of the mean, confidence intervals, prediction error, etc. As robust techniques these tests do not require normal distribution (EFron, B. and Tibshirani, R.1993).

The spatial trend was analysed with a factorial design: we separated the study area into four equal width regions from West to East, and four equal width regions from North to South (see Figure 1). Using these regions as ordered factors, the Kruskal-Wallis test was applied to reveal the statistical difference $\left(H_{0}\right.$ $\beta_{1}$ values' medians were from the same distribution for all regions; $H_{1}: \beta_{1}$ values' medians differ at least for one region from the others). The trend was justified with the JonckheereTerpstra test (AlI, A. et al. 2015). Both the Kruskal-Wallis and the Jonckheere-Terpstra tests are non-parametric tests which do not require the normal distribution; furthermore, we applied permutation with 5,000 repetitions for better representation of the median of the statistical population. Two-way factorial ANOVA was applied to reveal whether there is a statistical interaction between the spatial trend from West to East and North to South. Statistical analysis was performed in R 3.5.2 (R Core Team, 2018) with the clinfun (Venkatraman, E.S. 2018) and the WRS2 (MAIR, P. and Wilcox, R. 2018) packages.

The sensitivity map was compiled using the $B_{1}$-values of the climatic variables. We classified these values to binary variables considering the upper quartiles for TMAX, TA and PET and the lower quartile for PREC as threshold values. Thus, the new map layers reflected the areas where the risk of drought tendencies was the highest (representing the most dangerous 25 per cent of the total area). We then merged the map layers with a simple addition, which showed those areas where the number of risky climatic factors (increase in TMAX, TA and PET and 
decrease in PREC) indicated the severity of the drought issue (from 0 to 4 , i.e. 0: no risk, 4: all climatic factors' trends exceeded the threshold). Map operations were performed in QGIS 3.6 (QGIS Development Team, 2019).

\section{Results}

\section{Annual and seasonal trends}

According to the robust ANOVA, all the studied climatic variables showed significant seasonal differences $(\mathrm{p}<0.05)$; i.e. all seasons differed from each other and all seasons' trend differed from the case when the trend was determined from the whole months of the years (annual) (Figure 2).

The rise of TMAX (Figure 2, a) was observed in all seasons except for autumn. In the case of autumn the decrease was more moderate than the rise in the rest of the seasons. The extent of the increase rate showed similarities in spring, summer and autumn but in winter it covered a larger interval.
Increase can be expected annually as well, and the steepness of rise had similar distribution to that in the first half year; however, it can be interpreted in a smaller range. Statements regarding TA (Figure 2, b) were similar with the difference that the variance was smaller in each season. It is worth noting that the distribution of the $\beta_{1}$ values had higher kurtosis in the summer compared to the rest. In the case of PREC (Figure 2, c), there were only small changes in spring and summer, while there was an increasing trend in autumn and a decreasing trend in winter. In the latter two cases, effects balance each other resulting in no significant changes in the distribution of annual precipitation just like in the case of spring and summer.

Regarding PET (Figure 2, d), a change typical for the mean and maximum temperatures can be observed, i.e. rise in spring, summer and winter, at more moderate rate in the latter case, and decrease in autumn with the difference that the extent of changes can be interpreted over a smaller interval and the magnitude of changes is one order greater.
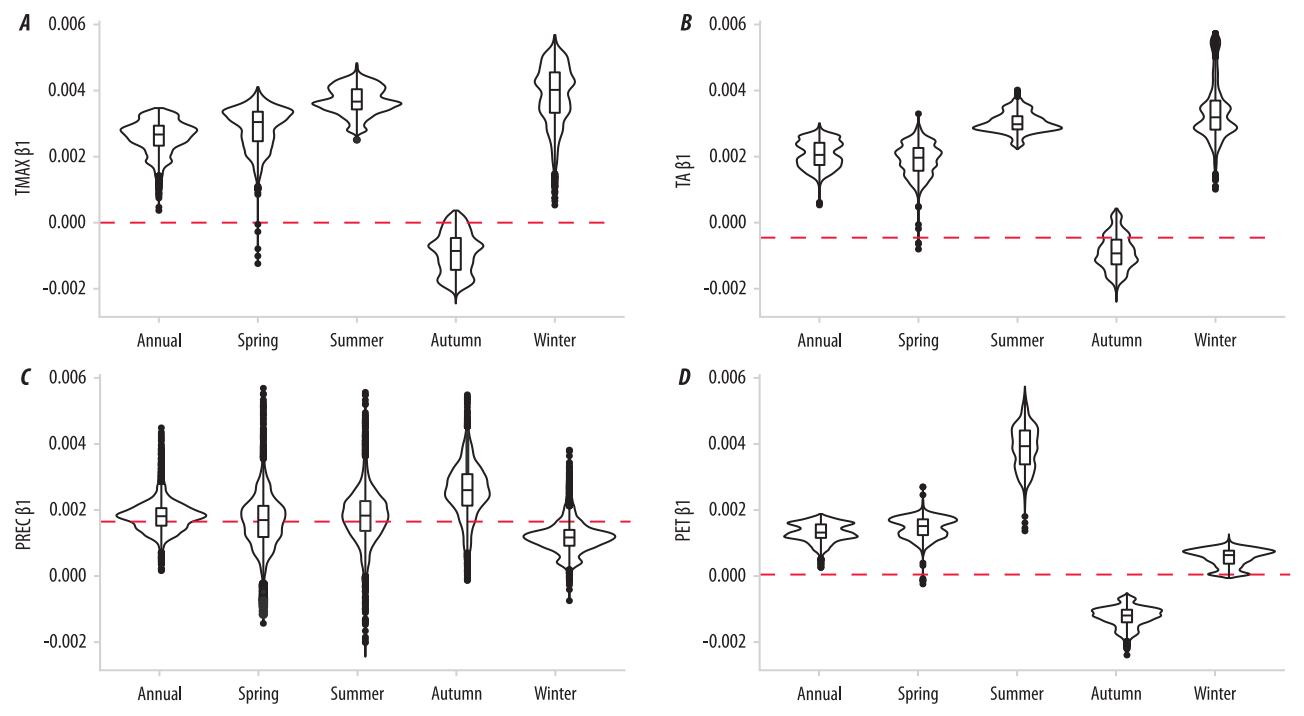

Fig. 2. Combined violin plot and boxplot diagrams of the climatic variables' regression $\beta_{1}$ values. - TMAX $=$ monthly maximum temperature; $\mathrm{TA}=$ monthly average temperature; $\mathrm{PREC}=$ monthly precipitation; $\mathrm{PET}=$ potential evapotranspiration. Zero level indicating no change. 


\section{Spatial trends}

We also studied whether the changes had a spatial trend regarding the main directions of the wind rose. We identified significant increasing trends both in case of the West-East and the North-South directions (see Figure 1). Kruskal-Wallis statistics revealed that there were significant changes when we split the dataset by regions, but did not point on the ones having those significant $(p<0.05)$ differences between the regions of \#1-\#4 or \#A-\#D (according to Figure 1).

Concerning the West-East direction, in the cases of TMAX, TA and PET medians decreased to the line of Eastern Carpathians for each climatic variable, but beyond this line (Region \#D) it was true only for summer and winter. For spring and autumn Region \#D had significantly larger values than the neighbouring Region \#C, and its $\mathrm{B}_{1}$-values were comparable (but not higher) than the most western Region \#A. PREC, similar to the previous observations, had the opposite pattern with increasing trend, but this was not a strict rule: while it was only a slight increase in spring and summer, it was definitely high in the autumn and there was a decreasing trend in the winter. Nevertheless, Region \#D had significantly lower values $(p<0.05)$ except summer when it was significantly higher $(p<0.05)$. Each of the climatic variables had significant trends according to the Jonckheere-Terpstra test considering the direction from West to East (Table 1).

Analysing the regions from North to South, the TMAX medians had the largest values in the northern region (Region \#1) and then the trend started to decrease to south up to the line of the Southern Carpathians, where significantly higher $(\mathrm{p}<0.05)$ medians occur in spring, summer and winter. For autumn the trend is continuous, without any deviations. TA had almost a similar pattern but in this case, winter had also a continuously decreasing trend such as autumn; furthermore, Region \#1 had larger variance, and larger median values related to any of the climatic variables or seasons. In this direc-
Table 1. Differences of the trends from West to East based on the Kruskal-Wallis $(K-W)$ and the Jonckheere-Terpstra $(J-T)$ test

\begin{tabular}{l|r|r}
\hline \multirow{2}{*}{$\begin{array}{c}\text { Climatic } \\
\text { variable }\end{array}$} & \multicolumn{2}{|c}{$\begin{array}{c}\text { Direction: West-East } \\
\text { Significance: } \mathrm{p}<0.001\end{array}$} \\
\cline { 2 - 3 } TMAX & K-W test & \multicolumn{1}{c}{$\mathrm{J}$-T test } \\
\hline TMAX spring & $2,463.40$ & $3,057,100$ \\
TMAX summer & $1,661.30$ & $3,780,100$ \\
TMAX autumn & $2,099.60$ & $2,572,100$ \\
TMAX winter & $3,665.00$ & $1,509,900$ \\
TA & 850.94 & $4,935,800$ \\
TA spring & $1,797.90$ & $3,596,600$ \\
TA summer & $1,550.60$ & $3,837,900$ \\
TA autumn & $2,271.20$ & $2,709,000$ \\
TA winter & $3,802.90$ & $1,539,300$ \\
PET & 831.57 & $4,740,300$ \\
PET spring & $2,500.60$ & $2,520,200$ \\
PET summer & $1,963.80$ & $3,110,500$ \\
PET autumn & $1,129.30$ & $3,543,300$ \\
PET winter & $2,342.70$ & $2,980,900$ \\
PREC & 838.32 & $3,934,300$ \\
PREC spring & 282.61 & $6,438,500$ \\
PREC summer & 324.21 & $5,482,100$ \\
PREC autumn & 460.42 & $6,424,800$ \\
PREC winter & 651.70 & $7,273,000$ \\
\hline
\end{tabular}

Notes: $\beta_{1}$ values of monthly temperature maximums (TMAX), of monthly mean temperatures (TA), of monthly mean precipitations (PREC), of monthly mean evapotranspiration (PET).

Table 2. Differences of the trends from North to South based on the Kruskal-Wallis (K-W) and the Jonckheere-Terpstra $(J-T)$ test

\begin{tabular}{l|r|r}
\hline \multirow{2}{*}{$\begin{array}{c}\text { Climatic } \\
\text { variable }\end{array}$} & \multicolumn{2}{|c}{$\begin{array}{c}\text { Direction: } \\
\text { Significance } \mathrm{p}<0.001\end{array}$} \\
\cline { 2 - 3 } & K-W test & \multicolumn{1}{c}{$\mathrm{J}$-T test } \\
\hline TMAX & 543.05 & $5,202,400$ \\
TMAX spring & 866.77 & $4,859,200$ \\
TMAX summer & 707.57 & $7,413,700$ \\
TMAX autumn & $1,058.40$ & $3,673,500$ \\
TMAX winter & 578.91 & $5,718,700$ \\
TA & $1,664.30$ & $3,363,500$ \\
TA spring & $1,307.50$ & $3,768,900$ \\
TA summer & 411.83 & $6,766,500$ \\
TA autumn & 665.74 & $4,062,300$ \\
TA winter & $1,642.10$ & $3,460,500$ \\
PET & 429.81 & $6,931,400$ \\
PET spring & 587.91 & $4,564,700$ \\
PET summer & $1,839.90$ & $8,715,000$ \\
PET autumn & $1,725.60$ & $2,983,200$ \\
PET winter & 879.06 & $7,603,700$ \\
PREC & $1,155.00$ & $3,502,000$ \\
PREC spring & $2,727.50$ & $2,168,200$ \\
PREC summer & 203.03 & $5,481,300$ \\
PREC autumn & 206.65 & $6,246,700$ \\
PREC winter & $2,285.70$ & $2,569,500$ \\
\hline NOE
\end{tabular}

Notes: TMAX, TA, PET and PREC $=$ for explanation see Table 1. 
tion PET's pattern was different as it had a decrease in the trend in spring and autumn, and an increasing trend in summer and winter. PREC had a definite and continuously decreasing trend from North to South in the spring and winter and had a slight decrease in summer and autumn. Each climatic variable had significant trends according to the Jonckheere-Terpstra test considering the direction of North to South (Table 2).

Combined effects of the spatial and seasonal factors

We combined the effect of the spatial features and found that there was a significant interaction effect of the two directions in case of each climatic variable (Table 3, Figure 3) according to the 2-way factorial ANOVA.

The analysis of the spatial trends of TMAX, regarding the $B_{1}$-values, revealed that the Regions \#1 and \#4 had almost the same character in maximum temperature change: steepness decreases from the western part of the area (Figure 3, a; \#A) then a quasi-stagnating state $(\# \mathrm{~B}, \# \mathrm{C})$ can be observed with a minimal rise (\#D). The trends of the two central regions (\#2 and \#3) were also similar to the differences that there was no decreasing tendency in the steepness of the trend in the eastern half of Region \#2 (in contrast to \#3).

Regarding TA (Figure 3, b), the slope of the trend decreased from West to East in all regions, but only the Region \#3 had straight trend in each location. Three regions ( $\# 1, \# 2$, $\# 4$ ) had decreasing trends up to the line of Carpathian Mountains, from where an increase began.
Trends observed in case of PET (Figure 3, c) had similar structures as TMAX with the difference that the location of Region \#1 and \#4 was the opposite: trend values of \#1 were smaller in the West and decreased towards the East. The starting value of \#A of \#4 can be ignored as no data are available from more than 75 per cent of the cell area; therefore, it cannot be compared with the others.

Precipitation increase (Figure 3, d) was observed in the foreland of the high mountains (on the western side of the Carpathians - \#C) and a decrease on the eastern slopes of the mountains. Region \#4 is an exception as the Southern Carpathians and the Romanian Plain can be found in its cells \#C and \#D with the lack of precipitation in the latter.

We also analysed the grid points from geospatial perspective and revealed the most sensitive areas (Figure 4). The largest part $(42.0 \%)$ was outside of the set threshold, i.e. of the upper quartiles. This class included Northeast and Southeast Hungary, Bánság (Banat), the Transylvanian Basin, certain parts of the Partium (Westernmost Romania), Slovakia and Transcarpathia (Figure 4, a).

31.6 per cent of the investigated area is characterized by the fact that only one climatic variable was above the threshold, altogether with the non-sensitive parts, almost the 75 per cent of the study area is a relatively stable region. The area where two climatic variables exceeded the threshold was 14.3 per cent, and the percentage was 7.5 for the areas where three of the climatic variables exceeded the quartiles. A relatively small area belonged to the riskiest class $(4.6 \%)$ mostly in Western Hungary and in Eastern Croatia.

Table 3. Differences between the regions regarding the directions of West to East (WE) and North to South (NS) and their statistical interaction (WE:NS) based on the Two-way factorial ANOVA

\begin{tabular}{l|c|c|c|r|r|r}
\hline \multirow{2}{*}{$B_{1}$ values } & \multicolumn{3}{|c|}{ Mean square } & \multicolumn{1}{c}{ F value } \\
\cline { 2 - 7 } & WE & NS & WE:NS & WE & \multicolumn{1}{c}{ NS } & WE:NS \\
\hline TMAX & $4.001 \times 10^{-4}$ & $5.9 \times 10^{-6}$ & $3.8 \times 10^{-6}$ & $2,382.0$ & 35.00 & 23.00 \\
TA & $1.313 \times 10^{-4}$ & $1.492 \times 10^{-4}$ & $3.866 \times 10^{-5}$ & $1,585.6$ & $1,801.80$ & 466.80 \\
PET & $3.544 \times 10^{-3}$ & $6.18 \times 10^{-4}$ & $2.8 \times 10^{-5}$ & $3,826.7$ & 667.52 & 30.46 \\
PREC & $5.86 \times 10^{-3}$ & $8.644 \times 10^{-2}$ & $4.442 \times 10^{-2}$ & 106.6 & $1,573.30$ & 808.40 \\
\hline
\end{tabular}

Notes: TMAX, TA, PET and PREC = for explanation see Table 1. Significance: $p<0.001$. 

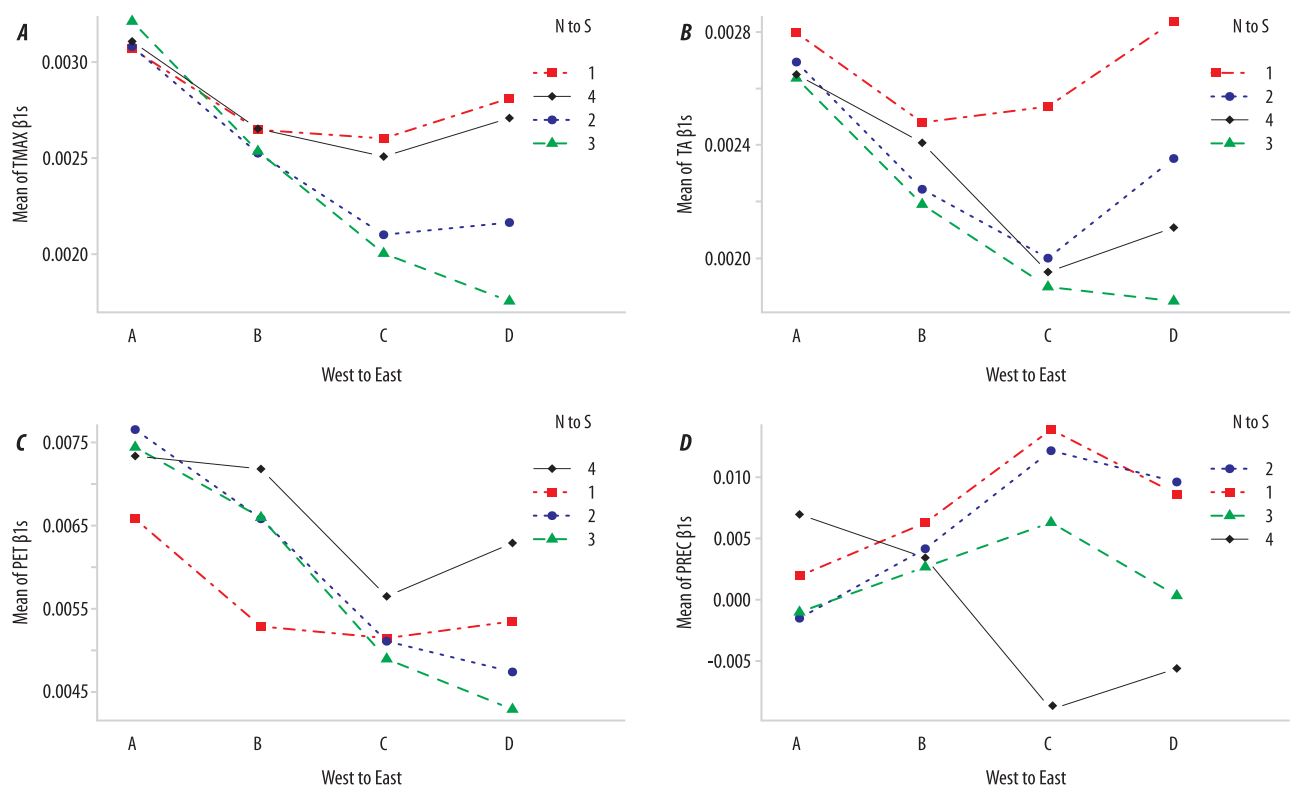

Fig. 3. Interaction plots of climatic variables by spatial features (region codes correspond with Fig. 1)

Unique features of the climatic variables showed that, generally, the eastern part of the Carpathian Basin and the Carpathian Mountains were rather consistently stable, while the western and southeastern areas were sensitive. Regarding TMAX, the areas West of the Danube fell in the most sensitive areas (Figure 4, b). TA had the same pattern with the difference that the coverage of the southwestern part of Hungary was more mosaic-like and that of the Ukraine beyond the Carpathians was homogeneous (Figure 4, c). Considering PET, the coverage of sensitive areas was mosaic-like in the areas West of a NNW-SSE striking line. In Hungary this meant the whole area West of the Danube, and $1 / 3$ of the area West of the Tisza river (Figure 4, d). The precipitation coverage showed the greatest spatial dispersion. The areas West of a NE-SW striking line were mosaic-like. In Romania this can be observed on the western side of Apuseni Mountains and in the Eastern and Southern Carpathians (Figure 4, e).

\section{Discussion}

Seasonal variations of maximum (TMAX) and mean temperatures (TA) were synchronous with each other in both seasonal and annual comparisons. The explanation can be found in the data providing the basis of variables as both values are obtained from hourly maximum and mean temperature data. Comparing TMAX and TA, the probability of maximum values was higher suggesting an increase in periods of heat waves. This was also supported by the diagram showing mean temperatures (see Figure 2) and the findings of Göndöcs, J. et al. (2018). The probability of precipitation increase occurred only in autumn, in an order of magnitude greater than in the case of temperature parameters. The even distribution of autumn excess precipitation could explain the decrease of mean and maximum temperatures.

Zhao, W. and Khalil, M.A.K. (1993) also found similar correlations between temperature and precipitation in the United States in summer, in the cases of Central and Southern 

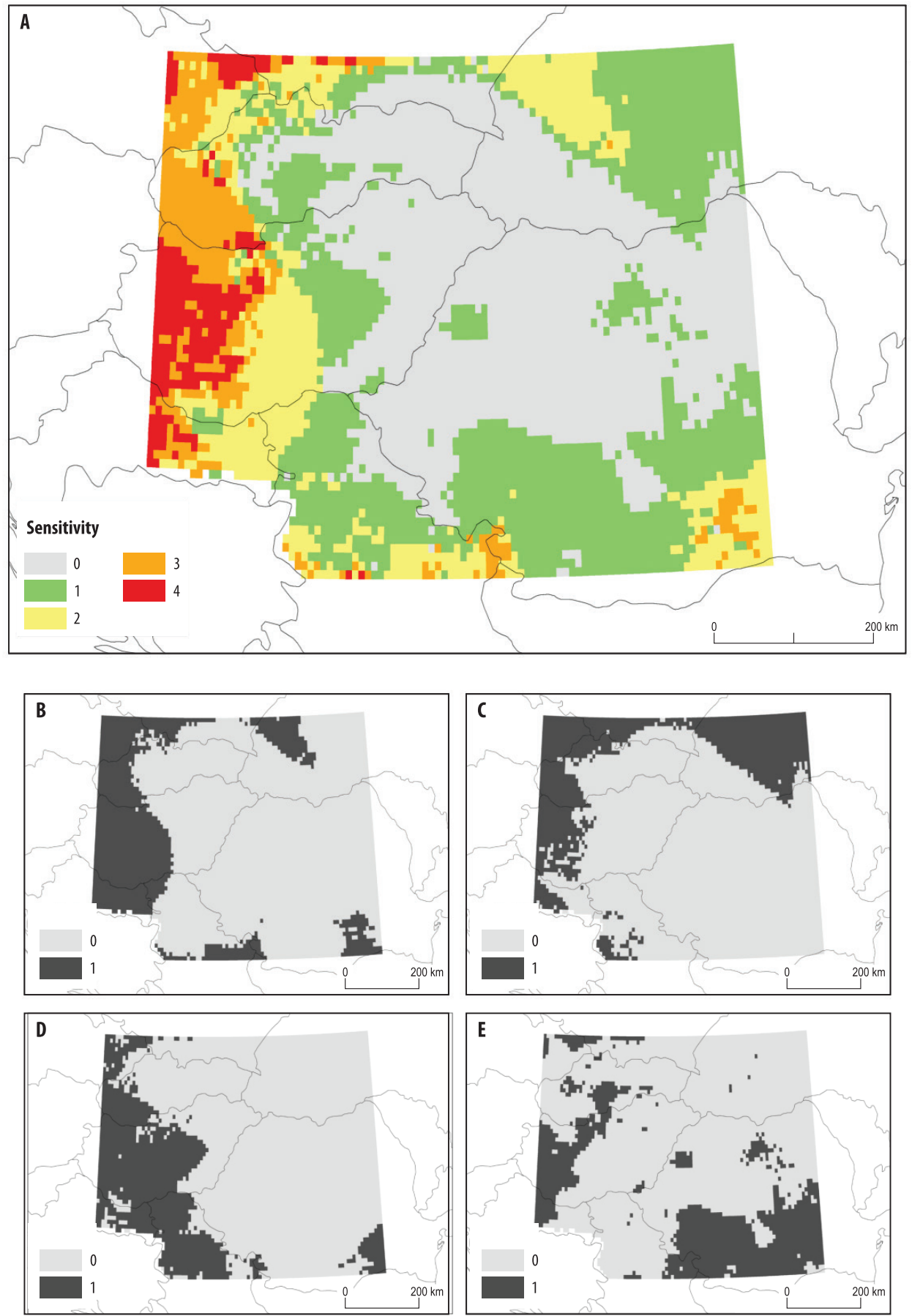

Fig. 4. Sensitive areas based on the observed highest trends ( $\beta_{1}$ values) for the climatic variables using the threshold value of upper quartiles. $-\mathrm{a}=$ sum of climatic variables where all maps were added (the higher the value, the more climatic variables exceeded the threshold); $\mathrm{b}=\mathrm{TMAX} ; \mathrm{c}=\mathrm{TA} ; \mathrm{d}=\mathrm{PET} ; \mathrm{e}=$ PREC 
Great Plains (Hungary, \#B2 and \#B3); it is important to note that the topography of these areas is similar to our study area. Ferrari, E. et al. (2018) also found a negative trend in the time series in Southern Italy, and also pointed to the fact that although the evidences of general warming were confirmed, seasonal changes can vary and can be contradicting. MilošEvić, D. et al. (2015) obtained similar results as in this study for precipitation and temperature trends in Vojvodina region of Serbia (regions \#B3 and \#B4) suggesting significant precipitation increase in autumn months while mean and maximum temperature decreased only in autumn for the period 1949-2013. The sign and distribution of PET and temperature parameters followed a similar characteristic with the difference that PET values were one order of a magnitude greater. The reason of this similarity can be found in temperature correlations as higher temperature generates greater evaporation and transpiration (Helfer, F. et al. 2012).

The geospatial structure of the spatial variation of maximum temperature showed an increase from West to East. The most important finding is that the increase was greater in the areas where the climate was cooler in a spatial average due to orographic conditions (major areas in the North-western [\#A1 and \#B1], North-eastern [\#D2 and \#D3] and Southern Carpathians [\#C4 and \#D4]; Regions \#1 to \#4, and in the western part of Hungary), in accordance with Szabó, S. et al. (2019). BlanKA, V. et al. (2013) and Mezósi, G. et al. (2016) predicted the largest changes in the Great Hungarian Plain (\#B2 and \#B3). This may seem to be a contradiction with our results, but some conditions are different: we analysed the trend and not the temperature change; i.e. a further increase of temperature can occur in the plains, too, but those areas are more affected where the temperature is currently cooler. The further, even a smaller increase of average and maximum temperature values can cause severe problems; thus, both land managers and urban planners have to be conscious of possible negative effects (e.g. water shortage, heat waves).
The Carpathians appeared to be a climatic boundary in this geospatial comparison: this phenomenon was reflected in Regions \#C and \#D in cells \#2 and \#3 with a greater decrease of the increasing tendency. This can be explained by the effect of orography (KoHLER, T. et al. 2014). KoHLER et al. also indicated that the change in the number of days per year with over $20 \mathrm{~mm}$ precipitation was usually a positive value in the Carpathians between 1960 and 2010, there were several areas in the mountains with decreasing tendencies, too. The number of intensive rainfalls and the decrease of total days of precipitation can result in an unbalanced water regime, flash floods and intensive erosion (PirkHoffer, E. et al. 2009; CZIGÁNy, Sz. et al. 2010, 2013; SzAвó, J. et al. 2015; ЈАКАв, G. et al. 2019). Regions of higher temperature and evapotranspiration and lower precipitation are endangered by wind erosion. Although wind erosion is common in dry areas, this issue will arise in regions where previously the vegetation and soil moisture protected the soils (PÁsztor, L. et al. 2016; NÉGYEsI, G. 2018).

PET showed a decreasing tendency from West to East in all regions; however, Region \#1 and \#4 (similarly to TMAX) showed stagnating (1) and increasing (4) tendencies respectively, proving earlier statements regarding the correlation between temperature and evaporation/transpiration in a geospatial perspective as well. Precipitation increased gradually up to Region $\# C$ then decreased in $\# 1, \# 2$ and $\# 3$ corresponding to the arriving moist air masses from the Atlantic Ocean and the orographic precipitation excess of the western slopes of the Carpathians (Kohler, T. et al. 2014). An exception was the southernmost Region \#4, which can be explained by the lack of enough data in cell \#A4 and by Mediterranean effects (Panthou, G. et al. 2018).

The spatial distribution of maximum and mean temperatures and PET above the upper quartile differed only in the considerably more mosaic-like map in the case of TA (see Figure 4, c), while PET represented a greater area compared to the maximum temperature. Areas below the lower quartile of 
precipitation had the greatest spatial heterogeneity. It is worth noting that an area outside the category can be observed in the region of Turnu Roşu Pass (Hungarian: Vöröstorony Pass; \#C4). The analysis of precipitation data revealed that monthly precipitation amounts showed major differences in this area in the 50 -year average. In a distance of 30-40 km differences of even 50-100 $\mathrm{mm}$ rain can be found among the grids within this distance.

\section{Conclusions}

CarpatClim ensured a detailed analysis of the time series in almost 500,000 $\mathrm{km}^{2}$. We aimed to involve the climatic trends into a detailed geospatial analysis.

We revealed that monthly average temperature, maximum temperature, evapotranspiration had positive trends except in autumn; precipitation did not follow this pattern, it had a negative trend in winter. The intensity of the changes in precipitation and evapotranspiration was one order of magnitude larger related to maximum and average temperature. There was a spatial trend from West to East, but the Carpathian Mountains had a relevant effect on it and changed the increasing values. There was a spatial trend from North to South and the Southern Carpathian Mountains also had a relevant effect in the southernmost region of the study area.

There was a significant statistical interaction between the directions (i.e. $\mathrm{E}-\mathrm{W}$ and $\mathrm{N}-\mathrm{S}$ ). Assigning the upper quartiles (in case of precipitation the lower quartile) as threshold helped to identify the regions most affected by the changing climate. Summing up the climatic variables identified those regions where the threshold exceeded more than one climatic variable; accordingly, the western part of Hungary and the eastern part of Croatia are the most sensitive regions for the predicted climatic changes. An important result is that largest changes can be expected in those regions where the climate is currently cooler related the warmest area of the Great Hungarian Plain.
Acknowledgements: The publication was supported by the National Research, Development and Innovation Office (NKFIH; 108755), and by the Higher Education Institutional Excellence Programme of the Ministry of Human Capacities in Hungary, within the framework of the $4^{\text {th }}$ thematic programme of the University of Debrecen. LE was supported by the European Union and the State of Hungary, co-financed by the European Regional Development Fund in the project of GINOP-2.3.2-15-2016-00009 'ICER'. SS was supported by the TUDFO/51757/2019-IT Thematic Excellence Project of the University of Debrecen (Space Science programme).

\section{REFERENCES}

Ali, A., Rasheed, A., Siddiqui, A.A., Naseer, M., WAsim, S. and АкнтаR, W. 2015. Non-parametric test for ordered medians: The Jonckheere-Terpstra test. International Journal of Statistics in Medical Research 4. 203-207.

Bartholy, J., Pongrácz, R. and Kis, A. 2015. Projected changes of extreme precipitation using multi-model approach. Időjárás 119. 129-142.

Bartholy, J., Pongrácz, R., Torma, C., Pieczka, I., Kardos, P. and Hunyady, A. 2009. Analysis of regional climate change modelling experiments for the Carpathian Basin. International Journal of Global Warming 1. (1-3): 238-252. Doi:10.1504/ IJGW.2009.027092

Blanka, V., Mezősi, G. and Meyer, B. 2013. Projected changes in the drought hazard in Hungary due to climate change. Időjárás 117. 219-237.

Bihari, Z., Babolcsai, Gy., Bartholy, J., Ferenczi, Z., Gerhátné Kerényi, J., Haszpra, L., Homokiné Ujváry, K., Kovács, T., Lakatos, M., Németh, Á., Pongrácz, R., Putsay, M., Szabó, P. and Szépszó, G. 2018. Climate. In National Atlas of Hungary. Natural environment. Eds.: Kocsis, K., Gercsák, G., Horváth, G., Keresztesi, Z. and Nemerkényi, Zs., Budapest, Geographical Institute, Research Centre for Astronomy and Earth Sciences, Hungarian Academy of Sciences, 58-69.

BradFord, R.B. 2000. Drought events in Europe. In Drought and Drought Mitigation in Europe. Eds.: Vogt, J.V. and Somma, F., San Francisco, US, Kluwer Academic Publishers, 7-20.

Czigány, Sz., Pirkhoffer, E. and Geresdi, I. 2010. Impact of extreme rainfall and soil moisture on flash flood generation. Időjárás 114. (1-2): 79-100.

Czigány, Sz., Pirkhoffer, E., Lóczy, D. and Balatonyi, L. 2013. Flash flood analysis for Southwest-Hungary. In Geomorphological Impacts of Extreme Weather: Case Studies from Central and Eastern Europe. Ed.: Lóczy, D., Dordrecht, Springer Science and Business Media, 67-82. Doi: 10.1007/978-94-007-6301-2_5 
Deák, B., Valkó, O., TöröK, P., Végvári, Zs., Hartel, T., Schmotzer, A., Kapocsi, I. and Tóthmérész, B. 2014. Grassland fires in Hungary - experiences of nature conservationists on the effects of fire on biodiversity. Applied Ecology and Environmental Research 12. 267-283. Doi:10.15666/aeer/1201_267283

DövÉNYI, Z. ed. 2010. Magyarország kistájainak katasztere (Inventory of microregions in Hungary). Budapest, MTA Földrajztudományi Kutatóintézet.

Efron, B. and Tibshirani, R. 1993. An Introduction to the Bootstrap. London, Chapman \& Hall/CRC.

Ferrari, E., Coscarelli, R. and Sirangelo, B. 2018. Correlation analysis of seasonal temperature and precipitation in a region of Southern Italy. Geosciences 8. 160. Doi:10.3390/geosciences8050160

Field, A., Miles, J. and Field, Z. 2012. Discovering statistics using R. Los Angeles-London-New York, SAGE.

Garamhegyi, T., Kovács, J., Pongrácz, R., Tanos, P. and Hatvani, I.G. 2018. Investigation of the climate-driven periodicity of shallow groundwater level fluctuations in a Central Eastern European agricultural region. Hydrogeology Journal 26. (3): 677-688.

Göndöcs, J., Breuer, H., Pongrácz, R. and Bartholy, J. 2018. Projected changes in heat wave characteristics in the Carpathian Basin comparing different definitions. International Journal of Global Warming 16. (2): 119-135. Doi: 10.1504/IJGW.2018.094552

Gulácsi, A. and Kovács, F. 2018. Drought monitoring of forest vegetation using MODIS-based normalized difference drought index in Hungary. Hungarian Geographical Bulletin 67. (1): 29-42. Available at https://doi.org/10.15201/hungeobull.67.1.3

Helfer, F., Lemckert, C. and Zhang, H. 2012. Impacts of climate change on temperature and evaporation from a large reservoir in Australia. Journal of Hydrology 475. 365-378. Doi: 10.1016/j. jhydrol.2012.10.008

Hellmann, J.J., Byers, J.E., Bierwagen, B.G. and Dukes, J.S. 2008. Five potential consequences of climate change for invasive species. Conservation Biology 22. (3): 534-543. Doi: 10.1111/j.1523-1739.2008.00951.x

JaKab, G., Bíró, T., Kovács, Z., PApp, Á., Sarawut, N., Szalai, Z., Madarász, B. and Szabó, S. 2019. Spatial analysis of changes and anomalies of intense rainfalls in Hungary. Hungarian Geographical Bulletin 68. (3). 241-253.

Kertész, Á. 2016. Is desertification a problem in Hungary? Acta Geographica Debrecina Landscape and Environment 10. (3-4): 242-247. Doi: 10.21120/ LE/10/3-4/18

Kertész, Á. and Mika, J. 1999. Aridification - Climate change in South-Eastern Europe. Physics and Chemistry of Earth (A) 24. 913-920. Doi:10.1016/ S1464-1895(99)00135-0

Kohler, T., Wehrli, A. and Jurek, M. 2014. Mountains and climate change: A global concern. Sustainable Mountain Development Series. Bern, Switzerland, Centre for Development and Environment (CDE),
Swiss Agency for Development and Cooperation (SDC) and Geographica Bernensia.

KovÁcs, F. 2018. NDVI/EVI monitoring in forest areas to assessment the climate change effects in Hungarian Great Plain from 2000. Proceedings SPIE 10783. In Remote Sensing for Agriculture, Ecosystems, and Hydrology XX. 107831H. Doi: 10.1117/12.2325647

Kundrát, J.T., Simon, E., Gyulai, I., Lakatos, G. and TóтHмÉRÉsz, B. 2016. Short-term weather fluctuation and quality assessment of oxbows. Időjárás 120. (3): 301-313.

Lakatos, M., Szentimrey, T. and Bihari, Z. 2011. Application of gridded daily data series for calculation of extreme temperature and precipitation indices in Hungary. Időjárás 115. (1-2): 99-109.

Lakatos, M., Szentimrey, T., Bihari, Z. and Szalai, S. 2013. Creation of a homogenized climate database for the Carpathian region by applying the MASH procedure and the preliminary analysis of the data. Időjárás 117. (1): 143-158.

MaIR, P. and Wilcox, R. 2018. Robust Statistical Methods Using WRS2. Available at https://cran.r-project.org/ web/packages/WRS2/vignettes/WRS2.pdf

Meehl, G.A., Stocker, T.F., Collins, W.D., Friedlingstein, P., Gaye, A.T., Gregory, J.M., КitoH, A., Knutti, R., Murphy, J.M., Noda, A., Raper, S.C.B., Watterson, I.G., Weaver, A.J. and Zhao, Z.-C. 2007. Global Climate Projections. In Climate Change 2007: The Physical Science Basis. Contribution of Working Group I to the Fourth Assessment Report of the Intergovernmental Panel on Climate Change. Eds.: Solomon, S., QIn, D., Manning, M., Chen, Z., Marquis, M., Averyt, K.B., Tignor, M. and Miller, H.L., Cambridge-New York, Cambridge University Press, 748-845.

Mezősi, G., Blanka, V., Ladányi, Z., Bata, T., Urdea, P., Frank, A. and Meyer, B.C. 2016. Expected mid- and long-term changes in drought hazard for the SouthEastern Carpathian Basin. Carpathian Journal of Earth and Environmental Sciences 11.355-366.

MiкA, J. 2009. Changes in means and extremities of temperature and precipitation in Hungary: One empirical and two model approaches with special reference to North-East Hungary. Thaiszai - Journal of Botany 19. 443-457.

Milošević, D., Savić, S.M., Stojanović, V. and Popov-RALJIĆ, J. 2015. Effects of precipitation and temperatures on crop yield variability in Vojvodina (Serbia). Italian Journal of Agrometeorology 20. 35-46.

MolnáR, K. and Mika, J. 1997. Climate as a changing component of landscape: Recent evidence and projections for Hungary. Zeitschrift für Geomorphologie 110. Supplementband, 185-195.

MórING, A. 2011. Weather of 2010. Légkör 56. 38-42. (in Hungarian)

NASA Jet Propulsion Laboratory (JPL) 2013. NASA Shuttle Radar Topography Mission Global 3 arc second. Version 3. $6^{\circ} \mathrm{S}, 69^{\circ} \mathrm{W}$ NASA EOSDIS Land Processes $D A A C$. Sioux Falls, South Dakota, USGS Earth 
Resources Observation and Science (EROS) Center. Available at https://lpdaac.usgs.gov https://doi. org/10.5067/MEaSUREs/SRTM/SRTMGL3.003 Accessed 19.01.2019.

NÉGYESI, G. 2018. Application possibilities of erodibility factor (EF) in the case of soils in Nyírség. Agrokémia és Talajtan 67. (2): 199-212.

PÁlfai, I. and Herceg, Á. 2011. Droughtness of Hungary and Balkan Peninsula. Riscuri si Catastrofe 9. (2): 145-154.

Panthou, G., Vrac, M., Drobinski, P., Bastin, S. and LI, L. 2018. Impact of model resolution and Mediterranean Sea coupling on hydro-meteorological extremes in RCMs in the frame of HyMeX and MEDCORDEX. Climate Dynamics 51. (3): 915-932.

PÁsztor, L., Négyesi, G., Laborczi, A., Kovács, T., LÁszLó, E. and Bihari, Z. 2016. Integrated spatial assessment of wind erosion risk in Hungary. Natural Hazards and Earth System Sciences 16. (11): 2421-2432.

Pirkhoffer, E., Czigány, Sz., Geresdi, I. and Lovász, Gy. 2009. Environmental hazards in small watersheds: flash floods - impact of soil moisture and canopy cover on flash flood generation. Riscuri si Catastrofe 7. (5): 117-129.

Pongrácz, R., Bartholy, J. and KIs, A. 2014. Estimation of future precipitation conditions for Hungary with special focus on dry periods. Idojjárás 118. 305-321.

QGIS Development Team 2019. QGIS Geographic Information System. Open Source Geospatial Foundation Project. Available at http://qgis.osgeo. org

R. Core Team, 2018. R: A Language and Environment for Statistical Computing. Vienna, R Foundation for Statistical Computing. Available at https://www.Rproject.org/

Ray, D.K., Gerber, J.S., McDonald, G.K. and West, P.C. 2015. Climate variation explains a third of global crop yield variability. Nature Communications 6. 59-89. Doi:10.1038/ncomms6989

Rusu, T., Moraru, P., Coste, C., Cacovean, H., Chetan, F. and Chetan, C. 2014. Impact of climate change on climatic indicators in Transylvanian Plain, Romania. WFL Publisher Science and Technology, Journal of Food, Agriculture and Environment 12. (1): 469-473. Doi: https://doi.org/10.1234/4.2014.4295

Spinoni, J., Lakatos, M., Szentimrey, T., Bihari, Z., Szalai, S., Vogt, J. and Antofie, T. 2015a. Heat and cold waves trends in the Carpathian region from 1961 to 2010. International Journal of Climatology 35. 1-13.

Spinoni, J., Szalai, S., Szentimrey, T., Lakatos, M., Bihari, Z., Nagy, A., Németh, Á., Kovács, T., Mihic, D., Dacic, M., Petrovic, P., Kržıć, A., Hiebl, J., Auer, I., Milkovic, J., Štepánek, P., ZahradníceK, P., Kilar, P., Limanowka, D., Pyrc, R., Cheval, S., Birsan, M-V., Dumitrescu, A., Deák, G., Matei, M., Antolovic, I., Nejedlík, P., Štastn'y, P., Kajaba, P., Bochnícek, O., Galo, D., Mikulová,
K., Nabyvanets, Y., Skrynyk, O., Krakovska, S., Gnatiuk, N., Tolasz, R., Antofie, T. and Vogt, J. 2015b. Climate of the Carpathian region in the period 1961-2010: climatologies and trends of 10 variables. International Journal of Climatology 35. 1322-1341. Available at https://doi.org/10.1002/ joc. 4059

Szabó, G., Singh, S.K. and Szabó, S. 2015. Slope angle and aspect as influencing factors on the accuracy of the SRTM and the ASTER GDEM databases. Physics and Chemistry of the Earth 83-84. 137-145.

SzABó, J., JАKAB, G. and SzaBó, B. 2015. Spatial and temporal heterogeneity of runoff and soil loss dynamics under simulated rainfall. Hungarian Geographical Bulletin 64. (1): 25-34.

Szabó, S., Elemér, L., Kovács, Z., Püspöki, Z., Kertész, Á., SingH, S.K. and BALÁzs, B. 2019. NDVI dynamics as reflected in climatic variables: spatial and temporal trends - a case study of Hungary. GIScience \& Remote Sensing 56. 624-644.

Szalai, S., Szinell, C.S. and ZoвокI, J. 2000. Drought monitoring in Hungary. In Early Warning Systems for Drought Preparedness and Drought Management. Eds.: Wilhite, D.A., Sivakumar, M.V.K. and Wood, D.A. Geneva, Switzerland, World Meteorological Organization, 182-199.

Szentimrey, T. 2011. Manual of homogenization software

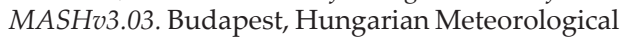
Service.

Szentimrey, T. and Bihari, Z. 2007. Mathematical background of the spatial interpolation methods and the software MISH (Meteorological Interpolation based on Surface Homogenized Data Basis). In Proceedings from the Conference on Spatial Interpolation in Climatology and Meteorology. Eds.: Szalai, S., Bihari, Z., Szentimrey, T. and LaKatos, M., Budapest, COST-European Science Foundation, 17-27.

Szentimrey, T., Bihari, Z. and Szalai, S. 2010. Comparison of Geostatistical and Meteorological Interpolation Methods (What is What?). In Spatial Interpolation for Climate Data: The Use of GIS in Climatology and Meteorology. Eds.: Dobesch, H., Dumolard, P. and Dyras, I., London, John Wiley and Sons, 45-56.

Szentimrey, T., Lakatos, M., Bihari, Z., Kovács, T., Szalai, S., Auer, I., Hiebl, J., Milkovic, J., Stepanek, P., Zahradnicek, P., Tolasz, R., Kilar, P., Pyrc, R., Limanowka, D., Cheval, S., Matei, M., Kajaba, P., Ivanakova, G., Bochnicek, O., Nejedlik, P., Statsny, P., Mihic, D., Petrovic, P., Savic, T., Skrynyk, O., Nabyvanets, Y. and Gnatiuk, N. 2012. Final report on quality control and data homogenization measures applied per country, including QC protocols and measures to determine the achieved increase in data quality. In Carpatclim Project Deliverable D1 12. Retrieved 22.04.2014. Available at http://www. carpatclim-eu.org/docs/ deliverables/D1_12.pdf 
Tate, E.L. and Gustard, A. 2000. Drought definition: A hydrological perspective. In Drought and Drought Mitigation in Europe. Eds.: Vogt, J.V. and Somma, F., Advances in Natural and Technological Hazards Research Series 14. San Francisco, Kluwer Academic Publishers, 23-48.

Török, P., Helm, A., Kiehl, K., Buisson, E. and VAlKó, O. 2018. Beyond the species pool: modification of species dispersal, establishment, and assembly by habitat restoration. Restoration Ecology 26. 65-72.

VAlkó, O., Török, P., DeÁk, B. and Tóthmérész, B. 2014. Review: Prospects and Limitations of Prescribed Burning as a Management Tool in European Grasslands. Basic and Applied Ecology 15. (1): 26-33. Doi:10.1016/j.baae.2013.11.002

VARGA, G. and Roetrig, C.-B. 2018. Identification of Saharan dust particles in Pleistocene dune sand- paleosol sequences of Fuerteventura (Canary Islands). Hungarian Geographical Bulletin 67. (2): 121-141. Doi: 10.15201/hungeobull.67.2.2
Venkatraman, E.S. 2018. Clinfun: Clinical Trial Design and Data Analysis Functions. $R$ package version 1.0.15. Available at https://CRAN.R-project.org/ package $=$ clinfun

Wilhite, D.A. 2000. Drought as a natural hazard: Concepts and definitions. In Drought: A Global Assessment. Vol. I. Ed.: Wilhite, D.A., London, Routledge, 3-18.

ZhaO, W. and KHalil, M.A.K. 1993. The relationship between precipitation and temperature over contiguous United States. Journal of Climate 6. 1232-1236. Doi: $10.1175 / 1520-0442$ 